\title{
ANALYSIS OF AMERICAN POLICIES TOWARD TAJIKISTAN SINCE 9/11
}

\author{
Dr. Faisal Javaid \\ Department of International Relations \\ Federal Urdu University of Arts Sciences and Technology \\ Karachi \\ faisal.javaid@fuuast.edu.pk
}

\begin{abstract}
Tajikistan is a landlocked state and has a unique position in the Central Asian region due to its border attached with Afghanistan, China, Kyrgyzstan, Uzbekistan, and near to Pakistan. It is the poorest among the Central Asian states with lack of energy resources. Tajikistan faced several challenges such as poor democratic performance, economic dependence on foreign remittances, unemployment, bad governance, and security threat. Next year after independence in 1992 the Tajik Civil War had started and ended in 1997, which had deep impacts on the country's economy and social life. Since 9/11 when the terrorist attack on the United States of America, Tajikistan got special attention due to its location. It condemned those attacks and keen to cooperate with American war against terrorism. This study focuses on American policies towards Tajikistan during 2001-2012. The paper also investigates American political, economic and security relations with Tajikistan and analyses the American interests and its strategic importance of Tajikistan towards America.
\end{abstract}

Keywords: America, Tajikistan, Afghanistan, War Against Terrorism, Central Asian region. 


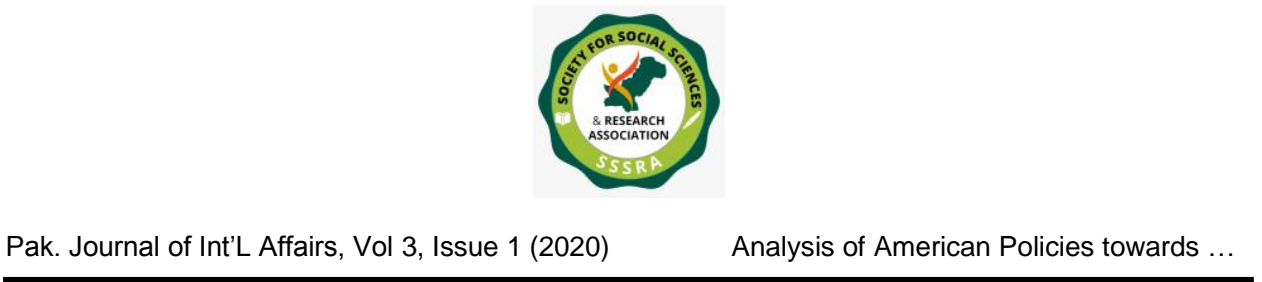

\section{Introduction}

Republic of Tajikistan was unique to the poorest of the fresh expresses that picked up freedom toward the end of 1991, afterward the fall of the previous USSR. It was a noteworthy nation in Central Asia by the ideals of its topographical area neighboring Afghanistan and China and its adequate water and different assets, yet it confronted ethnic and faction splits, profound destitution, poor administration, and other serious difficulties. It was a country facing serious security-related issues, with drugs and terrorism dominating the discourse and instability of its neighbor had affected Tajikistan. The new nation was soon plunged into a crushing common clash (1992-97) between contending provincial and different hobbies that endured until a peace settlement in 1997. Since autonomy, Tajikistan's outside strategy had concentrated on two fundamental undertakings making do as a country and securing universal help to keep up national security (Jonson, 2006, p.3). The Tajik civil war left the country and the regime highly dependent upon Russia for its national and regime security.

U.S. presence had significantly increased since Tajik independence in 1991, but the United States' influence in the region and importance for Tajikistan were far less than in the natural resources-rich regional states of Kazakhstan and Turkmenistan. The Tajiks established ties with the Americans upon independence while maintaining relations with Russia a policy aimed at balancing Moscow by avoiding heavy reliance on Russia and therefore securing Tajikistan's independence. From the conclusion in 1997 of the Tajik civil war, the US had sought for expanding its relations with Tajikistan through political and cultural accords and small-scale economic agreements. Afterward 9/11, terrorist assaults in the US, it brought new consideration regarding the security segment in Tajikistan. Tajikistan appeared to be ready to collaborate with the United States. Then again, it had since quite a while ago upheld the Afghan Northern Alliance's battle alongside the Taliban. Maybe in the wake of Russian gaging perspectives, Tajikistan quickly accessible utilization of Tajik airspace to U.S. powers, and several alliance strengths started to travel over Tajik runways and airspace. 


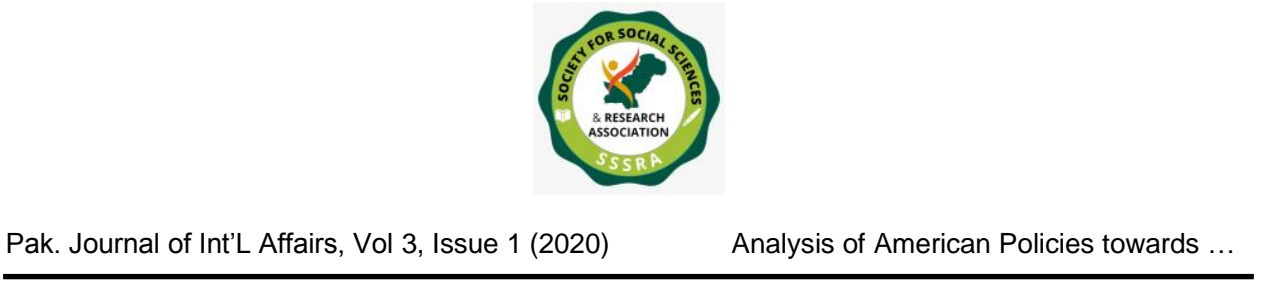

\section{Political Relations}

The US was one of the main nations to perceive Tajikistan as a free nation on 25 December 1991, after the break-up of the Soviet Union. America established diplomatic relations with Tajikistan on 14 February 1992. It was the second state who opened its Embassy in Dushanbe in March 1992 and Tajikistan opened its Embassy in Washington in December 2002 (Abdullaev, \& Akbarzaheh, 2010, p.363). Tajikistan was the main state in Central Asia to endure a genuine brutal common war, from 1992 to 1997. It was additionally the main state in Central Asia to determine such savagery through arranged compromise that incorporated a quantitative framework for the resistance in government. This resistance was captained by the Islamic Renaissance Party (IRP) (Crosston, 2013, p.84). The war had further set back monetary improvement in the nation. Tajikistan confronted a few issues neediness, wellbeing, instruction, transportation, vitality furthermore considerable dangers of terrorism and opiates trafficking from Afghanistan.

Tajikistan had been going subsequent to the common war by Emomali Rahmon, the USSR-time leader of a country homestead and loved better relationships with the USA. America had helped Tajikistan with its monetary and political advancement as it recouped from its considerate war. To help these endeavors, the US has given compassionate support and additionally political compromise dedicated to the advancement of majority rule government and upkeep of strength in the locale. America budgeted aid to Tajikistan was $\$ 988.57$ million from 1992 to 2010, it was the largest bilateral donor (Nichol, 2013, p.17). The United States had created a solid, multi-dimensional relationship that had advanced with a history of Tajikistan as a free country. The USA and Tajikistan had marked a few records on exchange and financial, philanthropic, security, military-specialized collaboration, battling against the universal terrorism, unlawful medications trafficking, society, instruction, and general wellbeing administrations and so forth (TajikAmerican Relations, 2007).

US-Tajik relations had created since September 11, 2001. The two nations now chipped in such territories as counter-opiates, counter- 


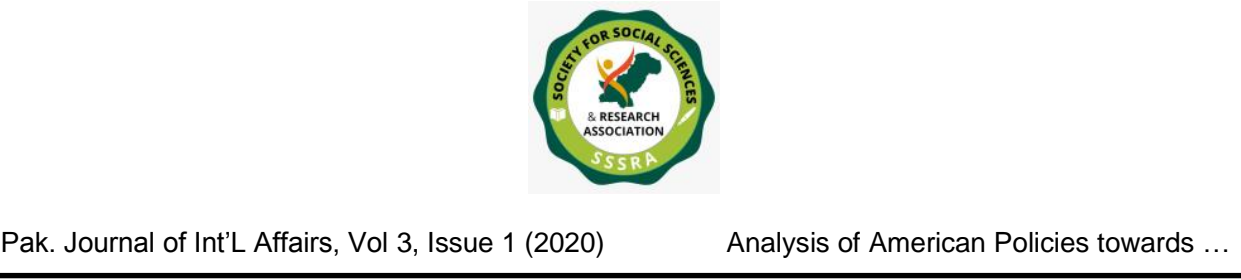

terrorism, non-multiplication, and local development and strength. Since Russian strengths withdrew from the Tajik-Afghan outskirt, the US had driven a global push to safeguard the nation's limits, keep the trafficking of opiates, and additionally material or engineering to be utilized as a part of weapons of mass devastation (Gorenburg, 2014, pp. $22 \&$ 55.). The vital occasion on respective relations was started of extension on August 26, 2007, in the Pyanj River joining Tajikistan with Afghanistan, which was built by the U.S. who subsidized $\$ 36$ million (Feigenbaum, 2006, p.11).

In December 2002, President Rahmon waged an official tour to the US, where he met with other officials along with President Bush. Discussions focused on the global war against terrorism, opposing drug trading, and financial restructuring and reduction of poverty in Tajikistan (Shoemaker, 2014, p.282). United States signed the establishment of Annual Bilateral Consultation (ABC) with each Central Asian state in 2009. To enhance cooperation in economy, trade and investment, science and technology, human rights and freedoms, border protection, combat drug smuggling and global terrorism and energy, etc., America and Tajikistan established Annual Bilateral Consultation. ABC held every year regularly from 2010 onward. (USA International Business Publications, 2015, p.26).

America provided to Tajikistan a counterweight to Russia's influence and focusing on democratization. During the visit of Condoleezza Rice to Tajikistan in October 2005, she conveyed to the Tajikistan about the requirement for law-based improvement to proceed and for decisions which were one stage along the fairway to be free, reasonable and comprehensive (Abdullo. 2007, pp. 76-77). The Tajik elite, like their regional counterparts, had become anxious about the lasting American objectives in the area since the Rose Revolution of Georgia outbreak and the following Orange Revolution in Ukraine. These were widely perceived as American inspired coups to install pro-Western governments in those countries as a mean to extend Washington's influence in the CIS countries. The March 2005 Tulip Revolution in Kyrgyzstan and Andijon event in Uzbekistan, particularly alerted the Tajik leadership, like other Central Asian states, is seen as the potential beginning of a series of color 


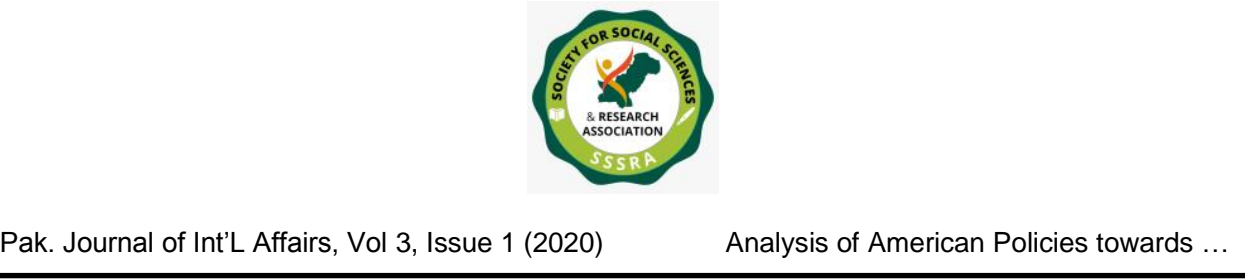

revolutions to expand U.S. influence in their region, which contains an increasingly dissatisfied population. It was not surprising that Tajikistan, a member of the SCO, sided with the other members in its July 2005 meeting to demand a clear timetable for the withdrawal of the American military from Central Asia, including Tajikistan (Blank, 2005). Tajik leadership was more reluctant to pursue close connections with the U.S and had expanded relations with Iran, China, and Russia, with which it had friendly and growing ties. It had also restricted the activities of Western, mainly U.S., NGOs such as the Soros Foundation, which Tajik president Emomali Rahmon accused in 2005 of acting to destroy Tajikistan's unity (Peimani, 2009, p.164).

Tajikistan had limited right of residents to change their legislature; torment and ill-use of prisoners and different persons by security powers; restraint of political activism and limitations on flexibilities of the statement and the free stream of data, including the rehashed blockage of a few autonomous news and long-range interpersonal communication sites and poor religious flexibility conditions and viciousness and oppression ladies. Other human rights issues included self-assertive capture; disavowal of the privilege to a reasonable trial; cruel and life-debilitating jail conditions; preclusion of global screen access to penitentiaries and defilement (U.S. Department of State, 2013). Secretary Clinton went by to Tajikistan in October 2011, cautioned the president that limitations on religious flexibility could help climbing religious discontent, more extensive human rights issues, the requirement for further popularity based changes, and called for opportunity of the press to be regarded. (The Express Tribune 2011, October 22). According to United States Commission on International Religious Freedom, (2013, p.11) states that on January 2012, the U.S. brought human rights issues up in yearly two-sided conferences with Tajikistan. Further according to Human Rights Watch, (2013) expressed that the human rights circumstance in Tajikistan stayed poor in 2012.

\section{Economic Relations}

Tajikistan was one of the poorest states in the region, and it relied 


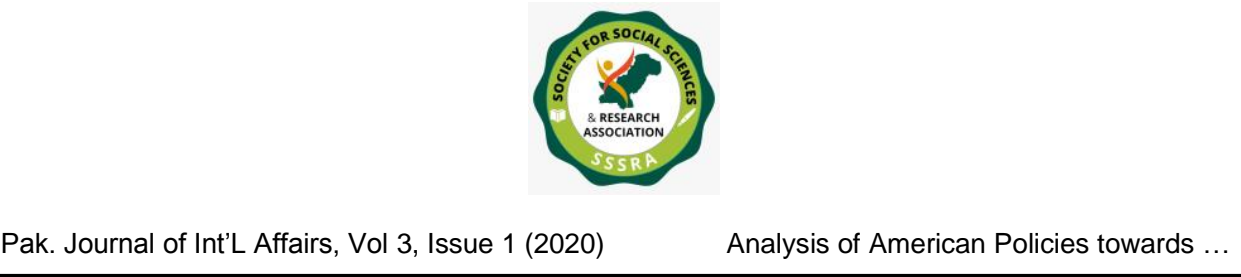

on upon the settlements and thing fares that made it powerless against worldwide monetary conditions. Tajikistan had marked an exchange and venture system concurrence with the US and other states of Central Asian building a provincial gathering to examine approaches to enhanced speculation atmospheres and extended exchange inside Central Asia. (International Trade Commission, 2005, p.3) The United States additionally backed aimed at Tajikistan's promotion toward the World Trade Organization.

Tajikistan had no large-scale resources of oil or gas; it was rich in coal, marble, gold, silver, tungsten, lead, uranium and zinc. It had one of the world's biggest plants for aluminum processing; moreover, it had also 65 percent of Central Asia's water resources (Bakhovadin, and Dodikhudoev, 2005, p.124). Inside the system of acknowledgment of the Agreement on advancing interest in Tajikistan, nine American-Tajik joint wanders and eight ventures having a place with the American speculators were working (Tajikistan-United States Relation, 2020). U.S.-Tajikistan signed an MoU on micro-financing in July 2002. The report turned into the essential venture for little business development in the nation, which had opened access to nationals to credit offices. United States had put over $\$ 1$ billion in Tajikistan. (US Embassy in Tajikistan, 2006).

The total trade volume between the Tajikistan and U.S. was $\$ 52.6$ million in 2013. The export made $\$ 51.9$ million and import was $\$ 0.7$ million. (United States Census Bureau, 2020). US exports to Tajikistan were mainly poultry, pharmaceutical preparations, and meat, imports from Tajikistan being precious, semiprecious, and imitation gems, fruits and household goods. The United States had been a significant assistance and a formative help contributor to encourage the execution of the Tajik peace treaty and for the relocation of relocated people. From 1992 to 2010, U.S apportioned an aid of $\$ 988.57$ million for Tajikistan, mainly for food, along with other humanitarian needs. The U.S. gave aid for Economic Growth (\$91.98 million), Governing Justly \& Democratically (\$126.1 million), Investing in People (\$56.72 million), Peace \& Security (\$179.85 million), Humanitarian (\$497.88 million) and crosscutting \& Program Support (\$36.02 million). (Nichol, 2009, July, pp. 17-21) 


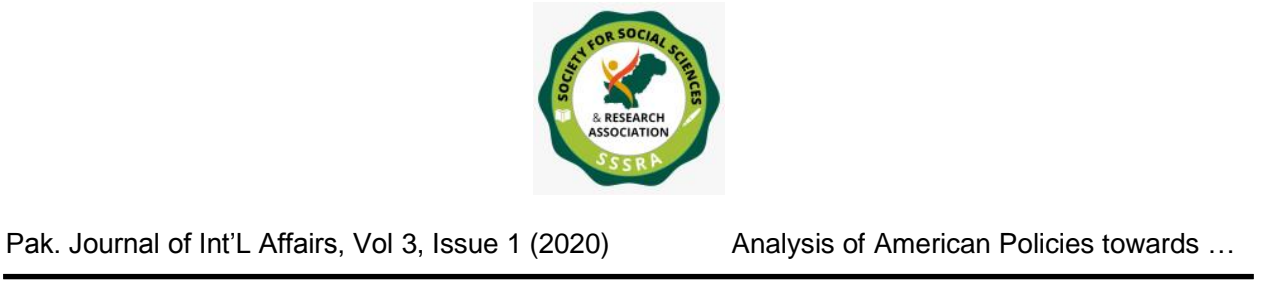

\section{Defense Relations}

The Sept. 11, 2001, terrorist assaults on America were events with major fallouts for Central Asia. As the U.S. started bombing Afghanistan after 9/11, its interest in the adjacent countries, including Tajikistan, augmented. Consequently, the U.S. military acquired landing and overflight rights in Tajikistan to support its operation in Afghanistan. Because it borders Afghanistan, Tajikistan's practical importance for such operation was more significant than that of Kazakhstan and Kyrgyzstan lacking a common border with Afghanistan (Peimani,2009, p.164)

The events created a completely new situation in Tajikistan, and it was opening favorable prospects. Tajikistan's foreign policy was activated, its relations with Western and Asian countries expanded. Tajikistan offered U.S the use of air bases in the anti-Taliban campaign in Afghanistan with Russia's consent (Jonson, 2006, p.57). Its participation in the U.S-led antiterrorist coalition became an instrument for Tajikistan to reach out to the world. As a result, its partnership with Russia was reduced but remained important and Tajikistan started to balance its policy in relation to Russia with the help of the wider cooperation with other big powers. (Jonson, 2006, p.4)

The first Central Asian republic was Uzbekistan to propose its backing aimed at the Afghanistan battle and opened its army installations and air space and in addition giving field clinics. It consented to a beginning arrangement on 7 October 2001, that accessible American troops could utilize the Khujand, Kulyab and Kurgan-Tyube airbases close to the Afghan borders (Rashid, 2008 p.83). Much to Central Command's aggravation, in any case, Uzbek authorities declined to permit transparently battle flying machine arrangement and demanded that the base be utilized fundamentally for helpful purposes. The USA and its alliance accomplices added these primary bases with divided refilling an air passageway concurrences with Kazakhstan, Turkmenistan, and Tajikistan's administrations, in spite of the fact that these were less pitched for political reasons (Wishnick, 2002, pp.13-14). Tajikistan likewise permitted the French military to utilize the Kulyab airbase on a possibility premise, basically for refueling, compassionate help, and over-flight 


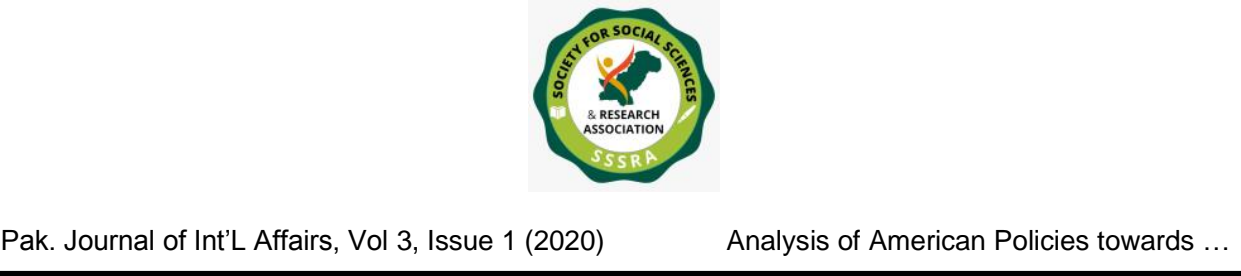

rights. (Leander, 2013, p.150) The government of Russia was not cheerful to acknowledge US army compels on previous Soviet domain, however concurred not to restrict the game plans the length of their were provisional and would be quiet after real battle actions in Afghanistan (Menon, 2003, p.192-194).

Secretary Hilary Clinton went to Tajikistan on 22 October, 2011 expressed that thanked the president Rahmon for the discriminating part Tajikistan had played in the global group's endeavors to make peace and security to Afghanistan, labeling Tajikistan a solid accomplice in such endeavors (Lillis, 2011, October 24). U.S concentrated on fringe security as the key issue in security collaboration. After 9/11, Tajikistan shockingly started getting military help from the United States for military training and education and military aid. This funding was adapted to change endeavors to guarantee that the Tajik army was well ready to direct antinarcotics and counterinsurgency actions (Oliker, and Shlapak, 2006, p.16). An understanding was marked on stretched out US aid to Tajikistan's outskirt security. Under a two-sided assertion marked on 5 February 2002, the USA was to give back to the Tajik Border Force with preparing and the buy of specialized and interchanges supplies. As a component of Tajikistan's support in the US-drove antiterrorist coalition, Tajikistan and the USA likewise created participation in sagacity gathering, particularly with respect to developments and occasions on both sides of the TajikAfghan fringe (Jonson, 2003, p.90).

The new Tajik-U.S. security participation was special. With consolation from the U.S headquarters that Tajikistan was deliberately essential nation, and guaranteed security help. Tajikistan then dedicated to joining NATO's Partnership for Peace Program. (Rashid, 2003, p111). America energized the Central Asians joins with the OSCE, the EU, and NATO. All the Central Asian republics with the exclusion of Tajikistan linked NATO's PFP by mid-1994. Tajikistan formally joined, in February 2002, the PFP program as the last of the states of Central Asia to do so and this provided further impetus to cooperation with the USA and the other countries (Jonson, 2004, p-91) Further, on November 2002, President Rakhmonov participated for the first time in a NATO summit meeting. In his speech, 


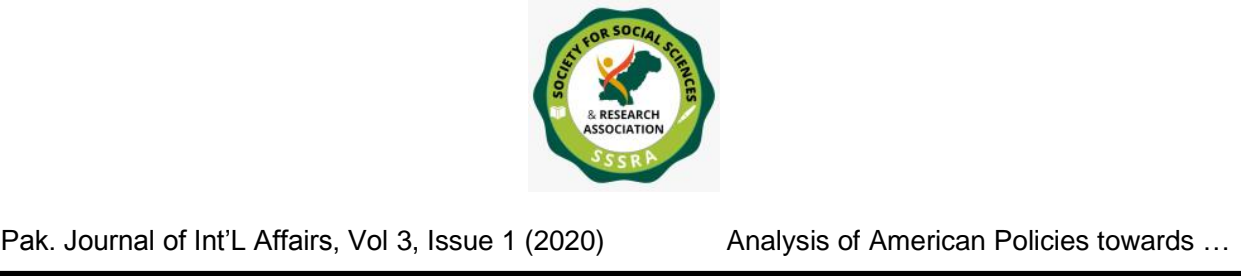

he stressed that participation in the PFP program was considered one of the fundamentals in Tajik foreign policy (Jonson, 2004, p.59).

NATO and Tajikistan effectively participated in the battle against terrorism and had created pragmatic participation in numerous different regions. They were creating functional participation in various zones through the nation's Individual Partnership Program (IPP), which was mutually concurred for a two-year period. Key regions included security and peacekeeping participation, particularly counter-terrorism collaboration and fringe security, emergency administration and common crisis arranging. The nation had likewise partaken in various practices with NATO Allies and other accomplice nations. (NATO Public Diplomacy Division. 2014).

As Crosston, (2016, p.104) work's state that there was an unpropitious change in the U.S. arrangement after 9/11 when the US lifted an eight-year-old arms deals boycott to Tajikistan in January 2002. According to Jamestown Foundation, (2002, May 3) expressed that in April 2002, America was giving army gear to Tajikistan. This was carried out as a prize for its backing in the war against dread. In early December 2002, Rakhmonov went on his first official visit to the USA and together with President Bush expressed a willingness for long-term strategic partnership and future cooperation against the threats to security from global terrorism, the spread of mass destruction weapons, as well as the drugs trade. Bush praised Rakhmonov for his stand in the international fight against terrorism (Jonson, 2006, p.59).

In January 2009, the U.S. and Tajikistan agreed on non-lethal supply to help armed actions of NATO and International Security Assistance Force in Afghanistan. Though the greatest terrestrial transportation lengthways this Northern Distribution Network navigated Uzbekistan to last ends in Afghanistan, Tajikistan aided as an option course aimed at a little portion of the materials. The area travel of several ISAF supplies ready for Afghanistan over Tajikistan started in March 2012 (Absher, 2013). US wanted to open a national preparing focus in Karatoga, Tajikistan, which included battalion mixes and weapons offices on 25 June 2010. The development expenses were assessed at \$10 million. It likewise 


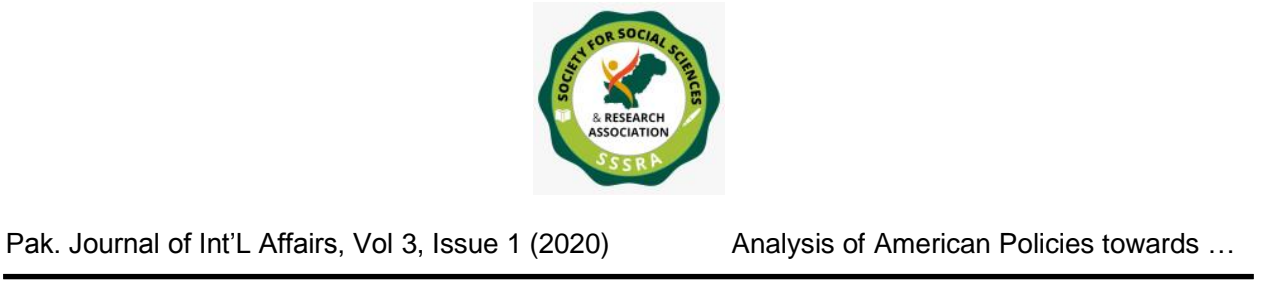

prepared Tajikistan's military about counter-narcotics and antiterrorism (Muzalevski, 2010).

The United States had likewise assumed a part in inside security issues in Tajikistan. In September 2010, U.S. Extraordinary Forces gave strategic backing to Tajik government troops in repulsing an endeavored Islamic aggressor operation in the Rasht valley.According to United States Commission on International Religious Freedom (2013, pp. 10-11), in an alternate episode, on the other hand, when Tajik troops were sent to the nation's southern Badakshan locale bordering Afghanistan in July 2012, U.S government office openly communicated sympathy toward regular citizen death toll and approached the administration to appreciation human rights, including those of prisoners, and to admiration press flexibility.

The United States had given USD179.9 million in security and peace support toward Tajikistan from 1992 to 2010, around 18\% of American help to the nation. Its support had been directed by the Energy, State, and Defense Departments, and had included Comprehensive Threat Reduction help, International Military Education and Training, Foreign Military Financing, Non-expansion, Partnership for Peace, De-mining, AntiTerrorism, and Related Programs, help, counter-opiates support, and international wrongdoing support. (Nichol, 2009, July, p.18)

\section{Conclusion}

Since autonomy, the main strategy of Tajikistan has been national security because of the Tajik civil war (1992-1997). The study analyzed that Tajikistan went back economically and socially, and the Country's dependence increased on Russia for national security and foreign remittances mostly coming from Russia. Tajikistan was a less developed country with bad economic situation in the region and didn't have enough energy resource. It became relevant to its position in the region toward American regional policy when the U.S. announced the war on terror in Afghanistan. It didn't have much attraction in past for America comparatively energy-rich regional states; Turkmenistan and Kazakhstan. Tajikistan already engaged against Taliban govt. and was supporting to Afghan Northern Alliance. It strictly condemned those attacks and was 


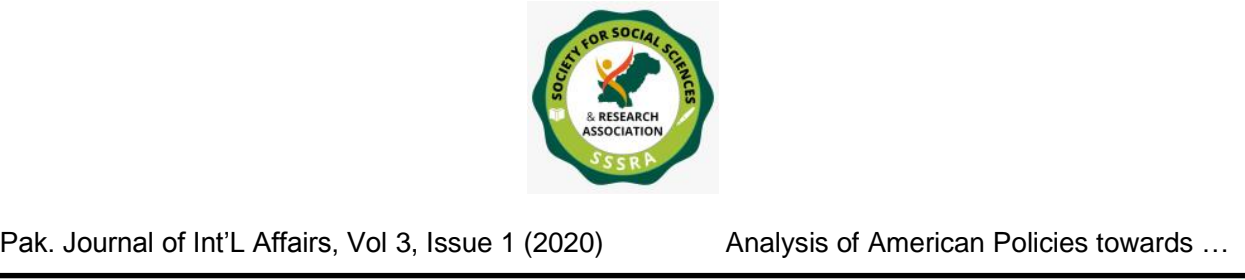

ready to cooperate in using its airbase and air space with the U.S. After color revolutions Tajik govt. had several concerns about American activities and after that, their relations were strained. American cooperation with Tajikistan was mainly focused on counter-terrorism. It engaged with Tajikistan through Annual Bilateral Consultation and was focusing on border security, drug smuggling, economy, science and technology, democratization and human rights.

\section{References}

Abdullaev, K. \& Akbarzaheh, S. (2010). Historical Dictionary of Tajikistan. Lanham: Scarecrow Press.

Abdullo, R. (2007). US Policy In Tajikistan: From Recognition Of Its Independence To Partnership. Central Asia and the Caucasus, 46 (4), 72-78.

Absher, L. (2013). Tajikistan: Turbulent Past, Future Uncertain. [Master Thesis The Florida State University] Department of Russian and East European Studies, FSU's Digital Repository https://diginole.lib.fsu.edu/islandora/object/fsu\%3A183640/

Bakhovadinov, A., \& Dodikhudoev, K. (2005). Tajikistan's Geopolitical Landmarks. Central Asia And the Caucasus, (1), 124-129.

Blank, S. (2005). Making Sense of The Shanghai Cooperation Organization's Astana Summit. Central Asia-Caucasus Analyst, 27.

Crosston, M. (2016). Fostering Fundamentalism: Terrorism, Democracy and American Engagement in Central Asia. London: Routledge.

Feigenbaum, E. A. (2006, August). Kazakhstan and the United States in a Changed World. In China and Eurasia Forum Quarterly (Vol. 4, No. 4, pp. 7-13). 
Gorenburg, D. (2014). External support for Central Asian military and security forces. SIPRI. Stockholm International Peace Research Institute, Working Paper Stockholm: Open Society Foundation,

Human Rights Watch. (2013). World Report 2013: Events of 2012. Bristol: Policy Press.

International Trade Commission. (2005). Operation of the Trade Agreements Program, the Year in Trade, 56th Report 2004. Washington D.C: DIANE Publishing.

Jamestown Foundation (2002, May 3) President Bush signed a memorandum on, April 19, 2002, approving the deliveries under the Foreign Assistance Act and Arms Control Act. Fortnight Review, 8 (9), p-7.

Jonson, L. (2003) Russia and Central Asia: Post-11 September, 2001.

Central Asia and the Caucasus, 19(1).83-94. http://www.cac.org/online/2003/journal_eng/cac-01/10.joneng.shtml

Jonson, L. (2004) Vladimir Putin and Central Asia: the shaping of Russian foreign policy. (Vol. 1.) London: IB Tauris.

Jonson, L. (2006). Tajikistan in the new Central Asia: geopolitics, great power rivalry and radical Islam. (Vol. 2). London: Ib tauris,.

Leander, A. (Ed.). (2013). Commercialising security in Europe: political consequences for peace operations. Routledge.

Lillis, J. (2011, October 24) Uzbekistan \& Tajikistan: Visiting Clinton Offers NDN Appreciation, Cautions on Religious Rights. https://eurasianet.org/uzbekistan-tajikistan-visiting-clinton-offersndn-appreciation-cautions-on-religious-rights.

Menon, R. (2003). The New Great Game in Central Asia. Survival, 45(2), 187-204. 
https://www.tandfonline.com/doi/abs/10.1080/00396338.2003.968 $\underline{8581}$

Muzalevski, R. (2010). The US Expands Military Ties With Tajikistan. Eurasia Daily Monitor, 7, 142.

NATO Public Diplomacy Division. (2014). Partners in Central Asia. Backgrounder, pp. 1-6 https://www.nato.int/nato_static_fl2014/assets/pdf/stock_publicatio ns/20140505_140505-Backgrounder_CentralAsia.pdf

Nichol, J. (2009, July). Tajikistan: Recent Developments and US Interests. Library Of Congress Washington DC Congressional Research Service.

Oliker, O., \& Shlapak, D. A. (2006). US interests in Central Asia: Policy priorities and military roles. Rand Corporation.

Peimani, H. (2009). Conflict and security in Central Asia and the Caucasus. Abc-Clio.

Rashid, A. (2003). Jihad: the rise of militant Islam in Central Asia. Yale: Yale University Press. https://ixtheo.de/Record/337525900

Rashid, A. (2008). Descent into chaos: the US and the failure of nation building in Pakistan, Afghanistan, and Central Asia. Penguin.

Shoemaker, M. W. (2014). Russia and The Commonwealth of Independent States 2014. Lanham: Rowman \& Littlefield.

Tajik-American Relations. (2007) Embassy of Tajikistan to the United States of America, New Hampshire Avenue, Washington http://www.tjus.org/tajikistan/tajik-american-relations,

Tajikistan-United States Relation. (2020). Ministry Of Foreign Affairs Of The Republic Of Tajikistan. 
https://mfa.tj/en/main/view/175/bilateral-relations-of-tajikistan-withunited-states-of-america.

The Express Tribune (2011, October 22) US pursues alternative supply route to Afghanistan: Hillary Clinton visited Tajikistan and Uzbekistan, two countries through which US funnels supplies into Afghanistan. The Express Tribune. https://tribune.com.pk/story/279960/us-pursues-alternative-supplyroute-to-afghanistan

U.S. Department of State. (2013). Bureau of Democracy, Human Rights and Labour. Country Reports on Human Rights Practices. https://www.state.gov/bureaus-offices/under-secretary-for-civiliansecurity-democracy-and-human-rights/bureau-of-democracyhuman-rights-and-labor/

United States Census Bureau. (2020). Trade in Goods with Tajikistan., https://www.census.gov/foreign-trade/balance/c4642.html.

United States Commission on International Religious Freedom (2013) Tajikistan. Washington: United States Commission on International Religious Freedom.

US Embassy in Tajikistan. (2006). The United States Embassy to Dushanbe, http://dushanbe.usembassy.gov/history.html.

USA International Business Publications. (2015). Tajikistan Mineral \& Mining Sector Investment and Business Guide: strategic information and regulation. (Vol.1). International Business Publications USA.

Wishnick, E. (2002). Growing US Security Interests in Central Asia. DIANE Publishing. 